\title{
Current Research: Selected Historic Caddo Allen Phase Vessels from the Deshazo Site (41NA13/27) on Bayou Loco, Nacogdoches County, Texas
}

Timothy K. Perttula

Heritage Research Center, Stephen F. Austin State University

Follow this and additional works at: https://scholarworks.sfasu.edu/ita

Part of the American Material Culture Commons, Archaeological Anthropology Commons, Environmental Studies Commons, Other American Studies Commons, Other Arts and Humanities Commons, Other History of Art, Architecture, and Archaeology Commons, and the United States History Commons

Tell us how this article helped you.

This Article is brought to you for free and open access by the Center for Regional Heritage Research at SFA ScholarWorks. It has been accepted for inclusion in Index of Texas Archaeology: Open Access Gray Literature from the Lone Star State by an authorized editor of SFA ScholarWorks. For more information, please contact cdsscholarworks@sfasu.edu. 


\section{Current Research: Selected Historic Caddo Allen Phase Vessels from the Deshazo Site (41NA13/27) on Bayou Loco, Nacogdoches County, Texas}

\section{Creative Commons License}

\section{(c) (1) \&}

This work is licensed under a Creative Commons Attribution-NonCommercial 4.0 International License 


\title{
Current Research: Selected Historic Caddo Allen Phase Vessels from the Deshazo Site (41NA13/27) on Bayou Loco, Nacogdoches County, Texas
}

\author{
Timothy K. Perttula \\ Archeological \& Environmental Consultants, LLC
}

Continuing with the on-going study of ancestral

Caddo ceramic vessels from East Texas Caddo sites, I document three ceramic vessels and a fourth ceramic vessel section from excavations at the Deshazo site (41NA13/27) by The University of Texas at Austin (UT) in 1975-1976. The Deshazo site is the best studied Allen phase settlement (Story 1982, 1995) in East Texas, and the archaeological investigations there indicates it was a small centralized hamlet of an affiliated group with a series of circular structures and an associated household or family cemetery. Most sites of the Allen phase were apparently occupied for only short periods of time, perhaps an average of 20 to 40 years, based on an analysis of structure rebuilding episodes at the Deshazo site (Good 1982:67-69).

The Deshazo site is situated just north of El Camino Real de los Tejas, on an alluvial fan near Bayou Loco, now submerged under the waters of Lake Nacogdoches (Figure 1). It is likely part of the 18th to early 19th century Hainai Caddo village of Bayou Loco (Prewitt 2019:Figure 4). A contemporaneous Hainai Caddo village was nearby to the west along the Angelina River and Legg Creek, with a Nacogdoche Caddo village on Bayou La Nana to the east. Archaeological investigations indicate it had a series of nine circular structures along with an associated household or family cemetery. The site was apparently occupied for only a short period of time between the late 17th and early 18th century, based on an analysis of structure rebuilding episodes, archaeomagnetic dates, and the size of the family cemetery. An AMS radiocarbon date obtained on a piece of split cane matting that adhered to a European hand bell from Burial 6 (Beta-432143; see Good 1982:Figure 34a) yielded a conventional radiocarbon age of 240 +/- 30 B.P. or A.D. 1710 +/- 30 (Tom Middlebrook, 2018 personal communication), and there are two archaeomagnetic dates from features: A.D. 1715 +/- 31 and A.D. 1710 +/- 34 (Story 1995:237).

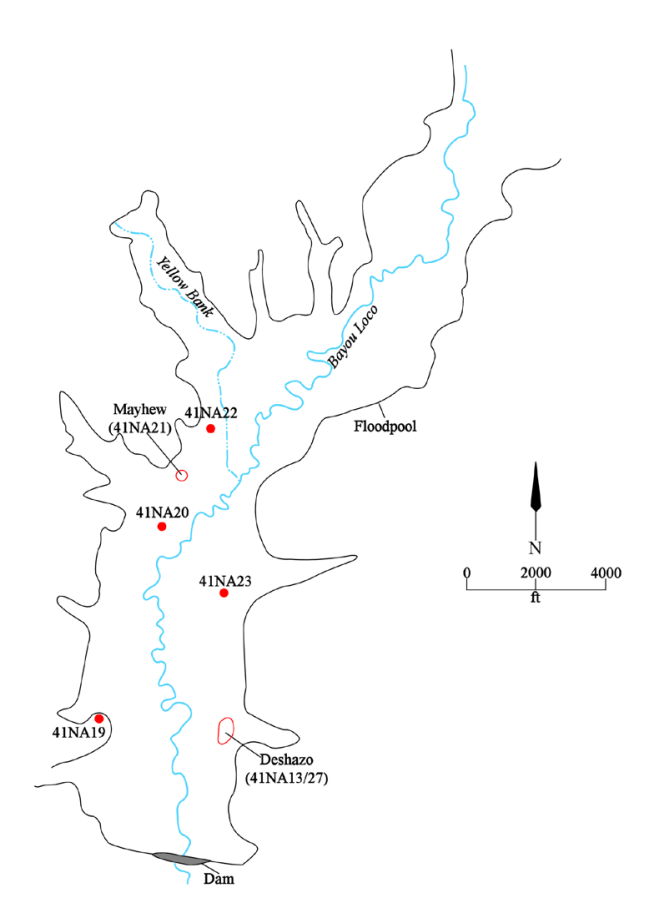

Figure 1. Location of the Deshazo site (41NA13/27) at Lake Nacogdoches, and other sites investigated there by the Texas Archeological Survey in the early 1970s.

The structures occurred in three different clusters, with evidence of structure rebuilding in northern (Structures 4-6) and southern clusters (Structures 1-3, 7, and 9), with an open courtyard or small plaza between them (Figure 2); Structure 8 was on the opposite side of the creek from the main settlement area. A communal trash midden accumulated immediately to the south of the southern cluster of house structures. The structures ranged between 9-12.2 $\mathrm{m}$ in diameter, each had a center post, and there were large clay-lined hearths inside as well as immediately outside several of the structures. Three children were buried in pits (Burials 11-13) dug through the floor of two of the structures in the village in Structure 1 (Area D, Unit 1) and Structure 9 (Area D, Unit 9). Each of these vessels had a single ceramic vessel left as a funerary offering. 


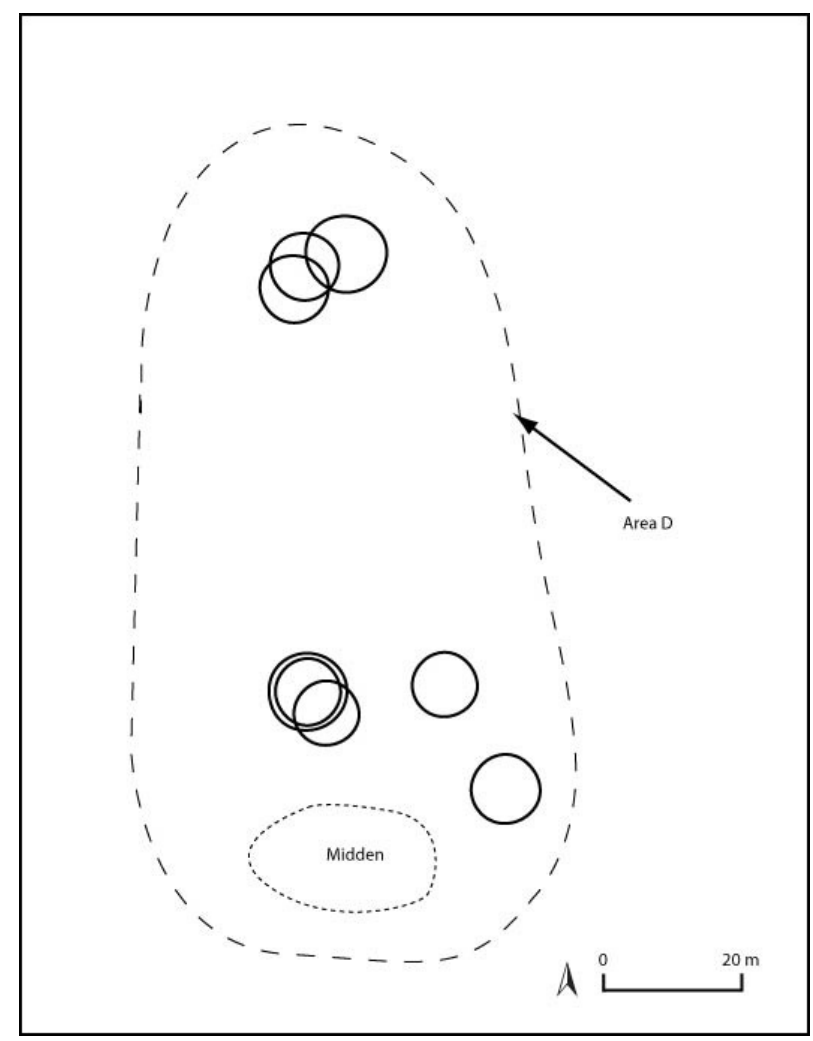

Figure 2. Plan of excavated structures and midden deposits at the Deshazo site (41NA13/27).

These vessels are documented in this article, along with a vessel section found near Hearth 1 in Structure 1 (Area D).

The site had small amounts of European trade goods found to only a limited extent in the village but they are much more common in burial contexts. The family cemetery had 10 adult individuals, buried in an extended position with the deceased's heads facing uniformly towards the northwest. The majority of the European goods used as funerary objects were glass beads ( $\mathrm{n}=4600+$ ) worn as necklaces that accompanied the deceased on the journey to the House of Death. Other funerary offerings included 13 ceramic vessels from burials in the Area A cemetery, several stone tools, a clay pipe, pigments, metal trade goods (iron knives and a bell), and a possible rattle.

Caddo domestic remains at this settlement included an abundance of plain and decorated ceramic fine wares (principally Patton Engraved) and utility wares, the latter usually bone-tempered and with brushed vessel bodies, triangular and stemmed arrow points (including Turney and Perdiz types), elbow pipes (plain and decorated), ground stone tools, and bone tools. These Caddo groups were successful agriculturists and hunters of wild game (see Henderson 1982).

Bob Turner and his father excavated nine burials (Burials 1-9) from Area A at the southern end of the Deshazo site in the late 1930s (Story 1995:1). They recovered 13 ceramic vessels from these burials, and they have been described by Fields (1995:203-208) and documented in detail by Perttula et al. (2010:431-443).

The fine ware vessels from the Area $\mathrm{A}$ cemetery include Patton Engraved, var. Allen and var. Patton bowls and jars (n=2) (see Perttula 2011:Figure 6-66a-b), Taylor Engraved carinated bowls ( $\mathrm{n}=1$ ), Natchitoches Engraved bowls ( $\mathrm{n}=1$ ), a possible Hume Engraved bowl, and unidentified engraved carinated bowls and compound bowls $(\mathrm{n}=2)$. The utility wares are incised-brushed jars $(\mathrm{n}=1)$, brushed-punctated jars $(\mathrm{n}=1)$, punctated jars $(\mathrm{n}=1)$, appliqued jars $(\mathrm{n}=1)$, and a brushed-appliqued jar $(n=1)$. There is also a plain bowl $(\mathrm{n}=1)$.

The four ceramic vessels recovered in the UT archaeological investigations are documented below:

\section{SITE NAME OR SITE NUMBER: Deshazo}

VESSEL NO.: Burial 11, Vessel 2 (see Good 1982:Figure 36d and Fields 1995:Figure 76b) in Area D, Unit 1 ; juvenile burial

VESSEL FORM: Carinated bowl

NON-PLASTICS AND PASTE: hematite

RIM AND LIP FORM: Direct rim and rounded lip

CORE COLOR: A (fired and cooled in an oxidizing environment)

INTERIOR SURFACE COLOR: reddish-brown; fire clouds on the body and base

EXTERIOR SURFACE COLOR: reddish-brown; fire clouds on the base 


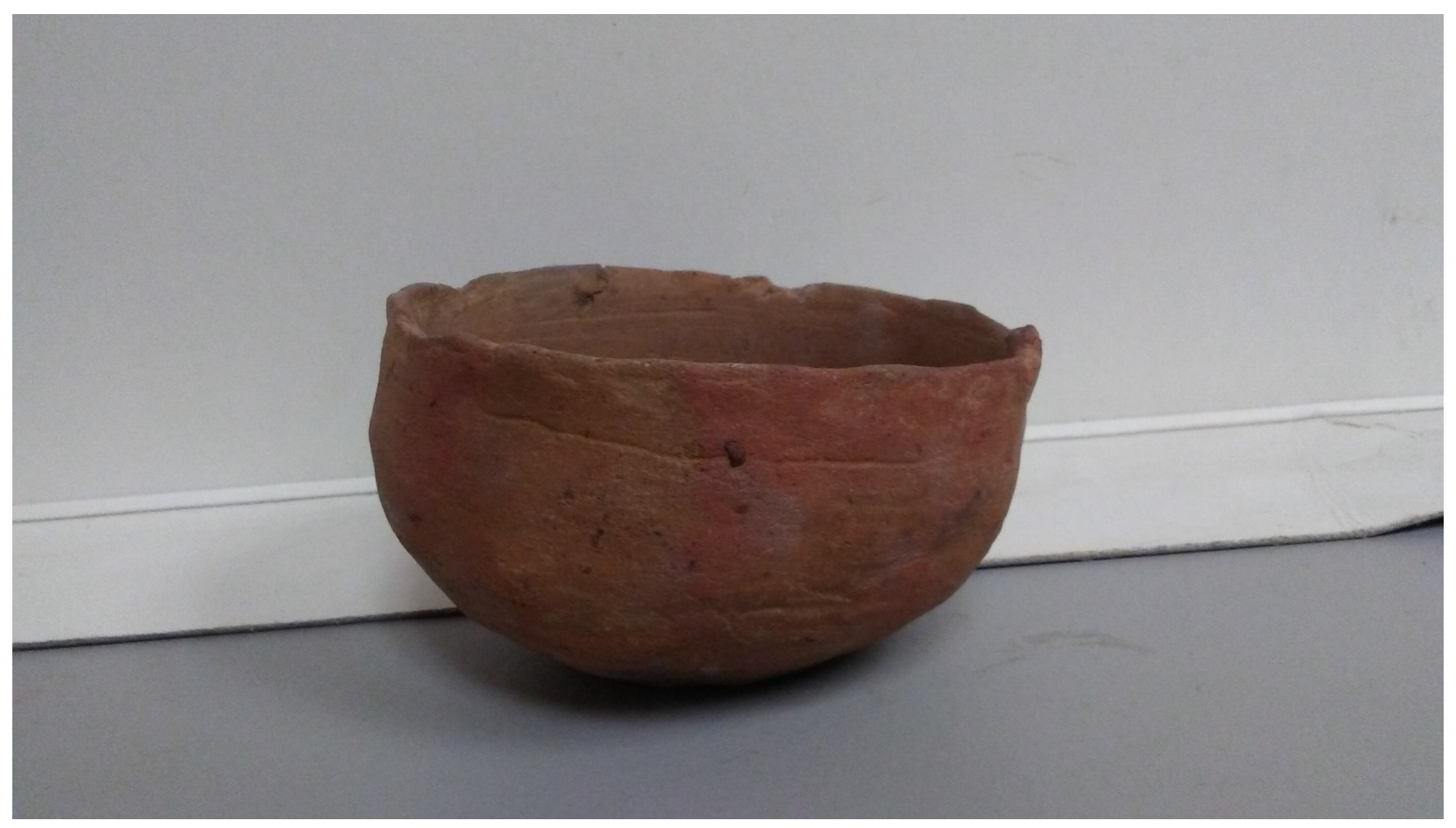

Figure 3. Plain carinated bowl (Vessel 2) in Burial 11 at the Deshazo site.

WALL THICKNESS (IN MM): rim, 4.4 mm

INTERIOR SURFACE TREATMENT: smoothed

EXTERIOR SURFACE TREATMENT: smoothed

HEIGHT (IN CM): 5.6

ORIFICE DIAMETER (IN CM): 9.5

DIAMETER AT BOTTOM OF RIM OR NECK (IN CM): 9.5

BASE DIAMETER (IN CM) AND SHAPE OF BASE:

$5.7 \mathrm{~cm}$, circular and flat

ESTIMATED VOLUME (IN LITERS): 0.3

DECORATION (INCLUDING MOTIF AND

ELEMENTS WHEN APPARENT): Plain (Figure 3)

PIGMENT USE AND LOCATION ON VESSEL: none

TYPE AND VARIETY (IF KNOWN): Unidentified plain ware
SITE NAME OR SITE NUMBER: Deshazo

VESSEL NO.: Burial 12, Vessel 9 (see Good 1982:Figure 37a and Fields 1995:Figure 77c); Area D, Unit 1, juvenile burial

VESSEL FORM: Globular carinated bowl

NON-PLASTICS AND PASTE: grog and hematite

RIM AND LIP FORM: Direct rim and rounded lip

CORE COLOR: A (fired and cooled in an oxidizing environment)

INTERIOR SURFACE COLOR: reddish-brown; fire clouds on the body and base

EXTERIOR SURFACE COLOR: reddish-brown

WALL THICKNESS (IN MM): rim, 3.7 mm; body, 6.3 $\mathrm{mm}$; base, $7.6 \mathrm{~mm}$

INTERIOR SURFACE TREATMENT: smoothed 


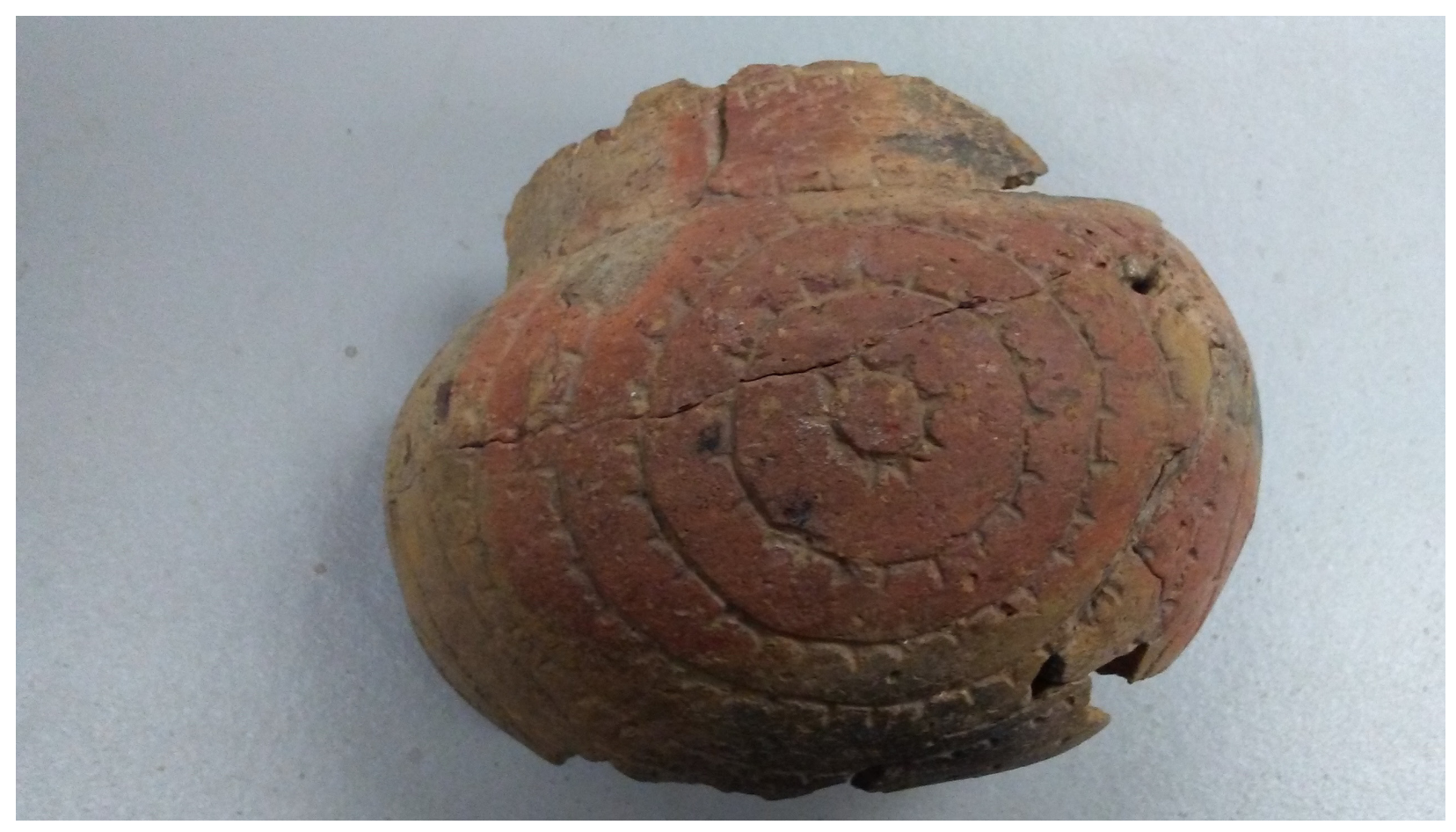

Figure 4. Patton Engraved, var. Fair carinated bowl (No. 9) in Burial 12 at the Deshazo site.

EXTERIOR SURFACE TREATMENT: smoothed

HEIGHT (IN CM): 7.0

ORIFICE DIAMETER (IN CM): 10.2

DIAMETER AT BOTTOM OF RIM OR NECK (IN CM): 10.2

BASE DIAMETER (IN CM) AND SHAPE OF BASE: N/A

ESTIMATED VOLUME (IN LITERS): 0.4

\section{DECORATION (INCLUDING MOTIF AND}

ELEMENTS WHEN APPARENT): The short rim panel on this vessel has upper and lower horizontal engraved lines with tick marks (Figure 4). The vessel body has four sets of concentric engraved circles with tick marks.

PIGMENT USE AND LOCATION ON VESSEL: none TYPE AND VARIETY (IF KNOWN): Patton Engraved, var. Fair (Perttula 2011:Figure 6-66d)
SITE NAME OR SITE NUMBER: Deshazo

VESSEL NO.: Burial 3, Vessel 3 (see Good 1982:Figure 36c and Fields 1995:Figure 76c); Area D, Unit 9, juvenile burial

VESSEL FORM: Goblet jar

NON-PLASTICS AND PASTE: grog and hematite

RIM AND LIP FORM: Direct rim and rounded, exterior folded, lip

CORE COLOR: A (fired and cooled in an oxidizing environment)

INTERIOR SURFACE COLOR: yellowish-brown; fire clouds on the base

EXTERIOR SURFACE COLOR: dark yellowishbrown; fire clouds on the rim and body

WALL THICKNESS (IN MM): rim, $6.9 \mathrm{~mm}$

INTERIOR SURFACE TREATMENT: none 


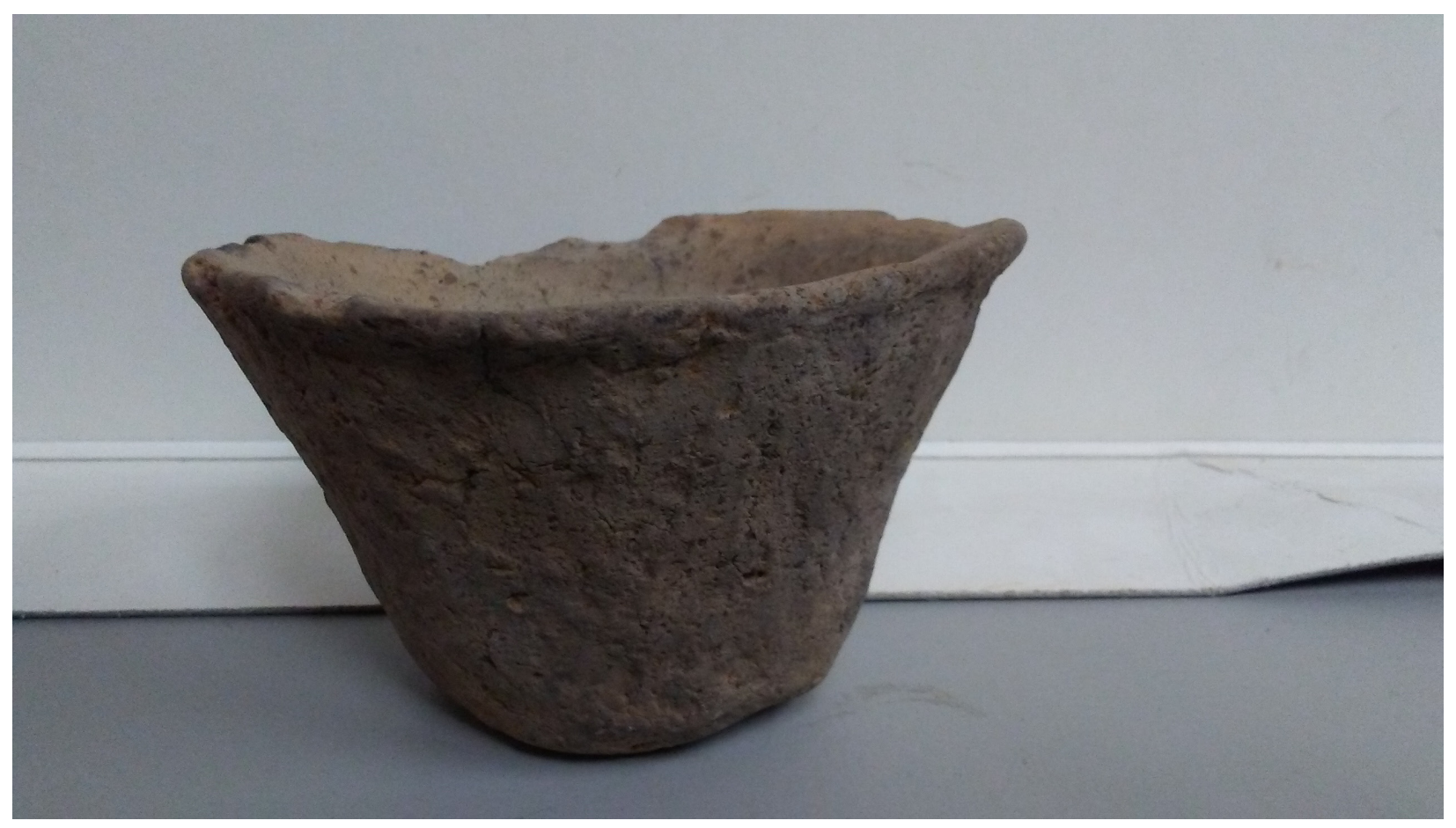

Figure 5. Plain jar (No. 3) from Burial 13 at the Deshazo site.

EXTERIOR SURFACE TREATMENT: none

HEIGHT (IN CM): 7.1

ORIFICE DIAMETER (IN CM): 10.5

DIAMETER AT BOTTOM OF RIM OR NECK (IN CM): 10.0

BASE DIAMETER (IN CM) AND SHAPE OF BASE:

$5.1 \mathrm{~cm}$, circular and flat

ESTIMATED VOLUME (IN LITERS): 0.4

DECORATION (INCLUDING MOTIF AND

ELEMENTS WHEN APPARENT): Plain (Figure 5)

PIGMENT USE AND LOCATION ON VESSEL: none

TYPE AND VARIETY (IF KNOWN): Unidentified plain ware
SITE NAME OR SITE NUMBER: Deshazo

VESSEL NO.: 58-21 (see Fields 1995:Figure 71); near Hearth 1 in Area D, Unit 1, Structures 1-3 (see Good 1982:Figure 17)

VESSEL FORM: Carinated bowl

NON-PLASTICS AND PASTE: grog

RIM AND LIP FORM: Direct rim and rounded lip

CORE COLOR: A (fired and cooled in an oxidizing environment)

INTERIOR SURFACE COLOR: reddish-brown; fire clouds on the body

EXTERIOR SURFACE COLOR: reddish-brown; fire clouds on the body

WALL THICKNESS (IN MM): rim, 10.5 mm; body, 8.1 $\mathrm{mm}$

INTERIOR SURFACE TREATMENT: smoothed 


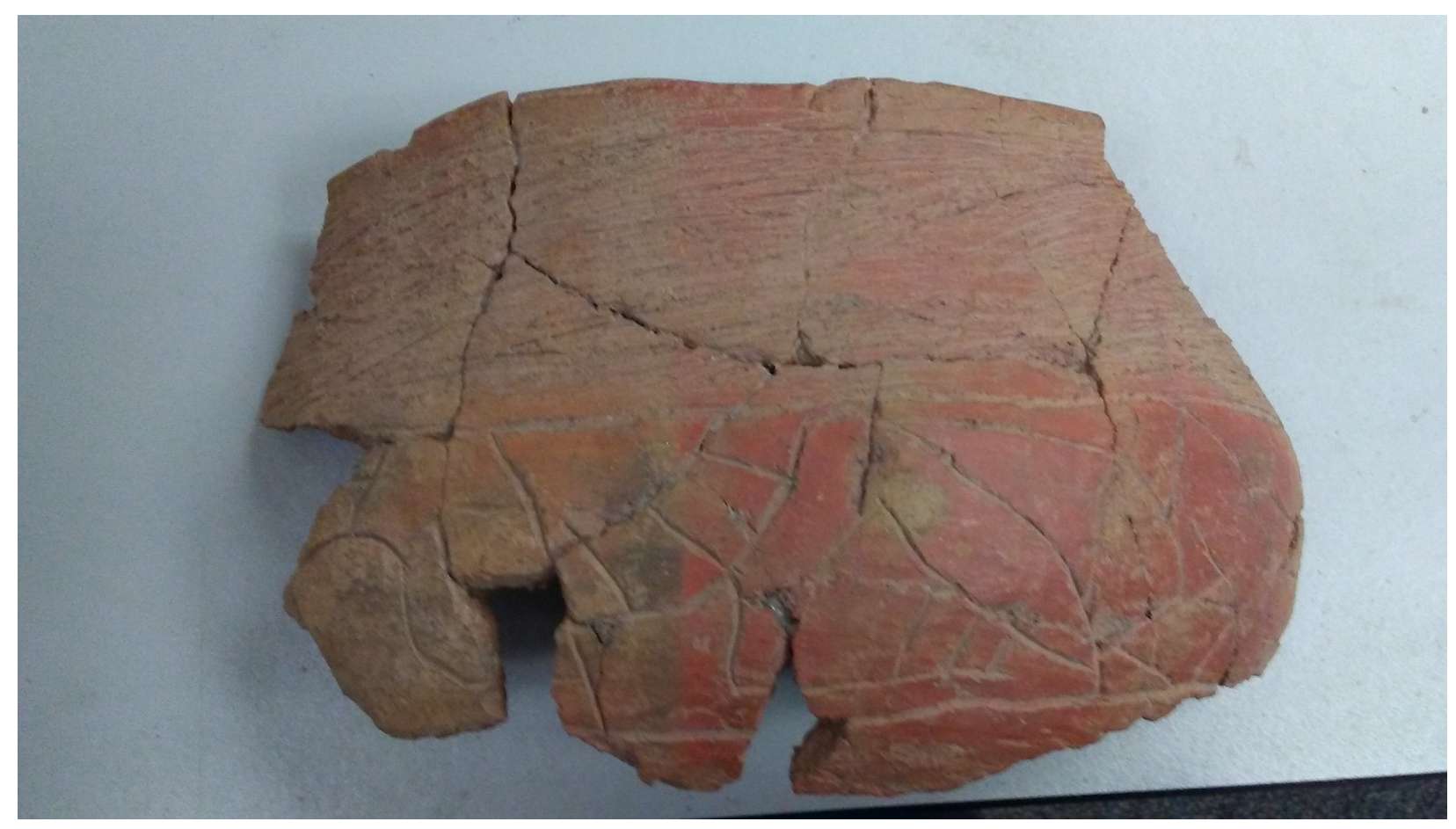

Figure 6. Brushed-engraved carinated bowl section (58-21) near Hearth 1 in Area D, Unit 1, at the Deshazo site.

EXTERIOR SURFACE TREATMENT: burnished on the body

HEIGHT (IN CM): 13.2+

ORIFICE DIAMETER (IN CM): 22.8+

DIAMETER AT BOTTOM OF RIM OR NECK (IN CM): $22.8+$

BASE DIAMETER (IN CM) AND SHAPE OF BASE: N/A

ESTIMATED VOLUME (IN LITERS): 1.8+

\section{DECORATION (INCLUDING MOTIF AND}

ELEMENTS WHEN APPARENT): The vessel rim has horizontal and overlapping brushed marks. The vessel body has a unique set of non-repetitive engraved elements, including diagonal opposed lines, large semicircles, diagonal hatched triangles, and diagonal hatched zones (Figure 6).
PIGMENT USE AND LOCATION ON VESSEL: none

TYPE AND VARIETY (IF KNOWN): Unidentified fine ware

The 17 ceramic vessels and vessel sections from the Deshazo site provide an excellent view of the character of an early 18 th century Allen phase funerary assemblage in the Angelina River basin in East Texas. The assemblage includes: Patton Engraved, var. Allen, var. Fair, and var. Patton bowls and jars $(\mathrm{n}=3)$, a Taylor Engraved carinated bowl, a Natchitoches Engraved bowl, a possible Hume Engraved bowl, a brushed-engraved carinated bowl section of unidentified type, and unidentified engraved carinated bowls and compound bowls $(\mathrm{n}=2)$. The fine wares comprise 53 percent of the vessel assemblage from the Deshazo site. The utility wares in burial features include incised-brushed jars $(\mathrm{n}=1)$, brushed-punctated jars $(\mathrm{n}=1)$, punctated jars $(\mathrm{n}=1)$, appliqued jars $(\mathrm{n}=1)$, and a brushed-appliqued jar $(n=1)$. The utility wares represent another 29 percent of the Deshazo vessel assemblage. Finally, there are also plain bowls $(\mathrm{n}=1)$, carinated bowls $(\mathrm{n}=1)$, and jars $(\mathrm{n}=1)$ in the assemblage, comprising 18 percent of the funerary vessels at the site. 


\section{Acknowledgments}

Thanks to Marybeth Tomka of the Texas Archeological Research Laboratory at The University of Texas at Austin for access to the vessels from the Deshazo site in their whole vessel collection. Lance Trask prepared Figures 1-2 for this article.

\section{References Cited}

Fields, R. C.

1995 Analysis of Native-Made Ceramics. In The Deshazo Site, Nacogdoches County, Texas, Volume 2: Artifacts of Native Manufacture, edited by D. A. Story, pp. 173-232. Studies in Archeology 21. Texas Archeological Research Laboratory, The University of Texas at Austin.

Good, C. E.

1982 Analysis of Structures, Burials, and Other Cultural Features. In The Deshazo Site, Nacogdoches County, Texas, Vol. 1: The Site, Its Setting, Investigation, Cultural Features, Artifacts of Non-Native Manufacture, and Subsistence Remains, edited by D. A. Story, pp. 51-110. Texas Antiquities Permit Series 7. Texas Antiquities Committee, Austin.

Henderson, J.

1982 Faunal Analysis. In The Deshazo Site, Nacogdoches County, Texas, Volume 1: The Site, Its Setting, Investigation, Cultural Features, Artifacts of Non-Native Manufacture, and Subsistence Remains, edited by D. A. Story, pp. 131-157. Texas Antiquities Permit Series No. 7. Texas Antiquities Committee, Austin.
Perttula, T. K,

2011 The Ceramic Artifacts from the Lang Pasture Site (41AN38) and the Place of the Site within an Upper Neches River Basin Caddo Ceramic Tradition. In Archeological Investigations at the Lang Pasture Site (41AN38) in the Upper Neches River Basin of East Texas, assembled and edited by T. K. Perttula, D. B. Kelley, and R. A. Ricklis, pp. 145-320. Archeological Studies Program Report No. 129, Texas Department of Transportation, Environmental Affairs Division, Austin.

Perttula, T. K., M. Walters, and B. Nelson

2010 Caddo Pottery Vessels and Pipes from Sites in the Big Cypress, Sulphur, Neches-Angelina, and Middle Sabine River Basins in the Turner and Johns Collections, Camp, Cass, Cherokee, Harrison, Morris, Titus, and Upshur Counties, Texas and Sabine Parish, Louisiana. Special Publication No. 10. Friends of Northeast Texas Archaeology, Pittsburg and Austin.

Prewitt, E. R.

2019 Bayou Loco: Investigations and Speculations. Journal of Northeast Texas Archaeology 80:1-16.

Story, D. A. (editor)

1982 The Deshazo Site, Nacogdoches County, Texas, Vol. 1. Texas Antiquities Permit Series No. 7. Texas Antiquities Committee, Austin.

1995 The Deshazo Site, Nacogdoches County, Texas, Volume 2: Artifacts of Native Manufacture. Studies in Archeology 21. Texas Archeological Research Laboratory, The University of Texas at Austin. 